\title{
Soil Nutrient Status Under Different Agro-Climatic Zones of Kashmir and Ladakh, India
}

\author{
KHURSHEED A. DAR ${ }^{2}$, K.A.SAHAF ${ }^{2}$, AFIFFA. S KAMILI², \\ LATIEF AHMAD', M.A MALIK ${ }^{2}$ and N.A GANAIE ${ }^{2}$ \\ ${ }^{2}$ Temperate Sericulture Research Institute, 'Division of Agronomy \\ Sher-i-Kashmir University of Agricultural Sciences \& Technology of Kashmir, \\ Shalimar J\&K 190025, India.
}

http://dx.doi.org/10.12944/CWE.11.1.13

(Received: January 04, 2016; Accepted: March 03, 2016)

\begin{abstract}
An investigations on nutrient analysis of soil under the different agro-climatic zones of Kashmir and Ladakh viz Temperate (Pattan, Baramulla), Sub temperate (Gurez, Bandipora) and Cold Arid (Kargil, Ladakh) was carried out during 2012 and 2013.The studies revealed that soils were alkaline in their reaction with slightly higher $\mathrm{pH}(8.2)$ recorded at Kargil followed by Pattan (7.9) and Gurez (7.6). Electrical conductivity was highest $\left(0.23 \mathrm{dSm}^{-1}\right)$ at Pattan and least at Kargil $(0.08$ $\left.\mathrm{dSm}^{-1}\right)$. Pattan soils were richer in organic carbon with an average value of $1.02 \%$. Varied results were obtained with respect to available soil nitrogen, the highest being recorded at Pattan with an average value of $372.8 \mathrm{~kg} \mathrm{ha}^{-1}$ Gurez recorded $251.5 \mathrm{~kg} \mathrm{ha}^{-1}$ and Kargil $184.9 \mathrm{~kg}^{-1}$. Pattan recorded maximum (22.45 $\left.\mathrm{kg} \mathrm{ha}^{-1}\right)$ soil available phosphorus while the sulphur was recorded highest $(53.40 \mathrm{~kg}$ $\left.\mathrm{ha}^{-1}\right)$ at Kargil. Among the three agro-climatic zones, (187.30 $\left.\mathrm{kg} \mathrm{ha}^{-1}\right)$, exchangeable calcium (17.56 centimole) and exchangeable magnesium (5.54 centimole).
\end{abstract}

Key words: Soil, Nutrient status, agro-climatic zones.

\section{INTRODUCTION}

Jammu and Kashmir is home to several valleys such as the Kashmir Valley, Tawi Valley, Chenab Valley, Poonch Valley, Sind Valley and Lidder Valley. The main Kashmir valley is $100 \mathrm{~km}$ (62 miles) wide and $15,520.3 \mathrm{~km}^{2}(5,992.4 \mathrm{sq}$ miles) in area. The Himalayas divide the Kashmir valley from Ladakh region of Jammu and Kashmir (India) while the Pir Panjal range, which encloses the valley from the west and the south, separates it from the Great Plains of northern India. Along the northeastern flank of the Kashmir Valley runs the main range of the Himalayas. This densely settled and beautiful valley has an average height of 1,850 metres $(6,070 \mathrm{ft})$ above sea-level but the surrounding Pir Panjal range has an average elevation of 5,000 metres (16,000 ft). (Anonymous, 2011)
Because of Jammu and Kashmir's wide range of elevations, its biogeography is diverse. Northwestern thorn scrub forests and Himalayan subtropical pine forests are found in the low elevations of the far southwest. These give way to a broad band of western Himalayan broadleaf forests running from northwest-southeast across the Kashmir Valley. Rising into the mountains, the broadleaf forests grade into western Himalayan subalpine conifer forests. Much of the northeast of the state is covered by the Karakoram-West Tibetan Plateau alpine steppe. Around the highest elevations, there is no vegetation, simply rock and ice. The soil also differs and Jammu \& Kashmir is having a wide variety of soils and soil texture varies from place to place and type of vegetation it supports also varies. Soil texture varies from rich deep alluvial soils to the thin and bare soils of high mountains. To ascertain the soil 
status under three agro climatic zones of Kashmir and Ladakh the present study was undertaken.

\section{MATERIALS AND METHODS}

The study was carried out during the years 2012 and 2013 at three different sites viz: Temperate Zone Pattan with latitude of $34^{\circ} 09^{1}$ and longitude of $74^{\circ} 33^{1}$ and $5306 \mathrm{ft}$ asl (District Baramulla), Sub-temperate Zone Gurez with latitude of $34^{\circ} 38^{1}$ and longitude of $74^{\circ} 44^{1}$ and $9601 \mathrm{ft}$ asl (District Bandipora) and Cold arid zone Kargil with latitude of $34^{\circ} 34^{1}$ and longitude of $76^{\circ} 04^{1}$ and $10745 \mathrm{ft}$ asl (District Ladakh) with the annual rainfall of $890 \mathrm{~mm}$, $1280 \mathrm{~mm}$ and $110 \mathrm{~mm}$ respectively. The design used for the experiment was RBD with twelve treatments and three replication for carrying out the study. Soil samples were collected at two different depths i.e. one feet and two feet from each agro-climatic zone by digging pits and taking a thin slice of soil. The samples were subjected to quartering and $200 \mathrm{~g}$ of each sample were collected, air dried in shade and then crushed with wooden mortar and pestle. The crushed samples were sieved through $2 \mathrm{~mm}$ sieve. A portion of each sample was sieved through $0.4 \mathrm{~mm}$ sieve for estimation of organic carbon. The samples were stored in sealed polythene bags. Soil $\mathrm{pH}$ and EC was measured in 1:2:5 overnight soil water suspension by conductivity meter and organic carbon was determined by Walkley and Black (1934) rapid titration method.The available nitrogen was estimated by alkaline potassium permanganate method given by Subbiah and Asija (1956), available phosphorus was estimated by method given by Olsen et al. (1954) available potassium was estimated by method given by Mervein and Peech (1950) and available sulphur was extracted with Morgans reagent having $\mathrm{pH} 4.8$ and determined by turbidimetric method given by Chesnin and Yien (1951), also the exchangeable calcium and exchangeable magnesium was estimated by a method given by Black (1965).

\section{RESULTS AND DISCUSSION}

Soil samples collected under all the three different agro-climatic zones were analysed to test their status. The results obtained are given in Table 1

\section{Soil pH}

The soils at all the three sites were alkaline. Pooled data showed that at Gurez, the average $\mathrm{pH}$ was 7.6 whereas at Kargil, the $\mathrm{pH}$ was higher with an average value of 8.2 and at Pattan, average $\mathrm{pH}$ was 7.9. However, no significant difference was observed among the three agro-climatic zones .

\section{Electrical conductivity (dSm ${ }^{-1}$ )}

Electrical conductivity was highest in the soil of Pattan and least in the soils of Kargil. Soils at Gurez recorded average electrical conductivity of 0.14 and at Kargil average electrical conductivity was 0.08 whereas at Pattan it was 0.23. Differences between three zones were significant.

\section{Soil organic carbon (\%)}

At Pattan soil was richer in organic carbon than other two sites under study. Pattan recorded organic carbon in the range of $1.01-1.14 \%$. Kargil soils had the least value of 0.27 of organic carbon. Gurez recorded an average value of $0.32 \%$.

\section{Available soil nitrogen (kg/ha)}

Soil nitrogen depicted a great variation in values as recorded in three zones. The highest soil nitrogen content was recorded at Pattan site with an average value of $372.8 \mathrm{~kg} / \mathrm{ha}$ followed by Gurez with an average value of $251.5 \mathrm{~kg} / \mathrm{ha}$ and least at Kargil recording soil nitrogen of $184.9 \mathrm{~kg} / \mathrm{ha}$.

\section{Available soil phosphorus ( $\mathrm{kg} / \mathrm{ha}$ )}

Pattan recorded maximum soil phosphorus during both the years of study with an average value of $22.45 \mathrm{~kg} / \mathrm{ha}$. This was significantly higher than the values recorded at Kargil (17.40) and Gurez (18.23).

\section{Available soil potassium (kg/ha)}

Soil potassium was highest at Pattan recording an average value of $187.3 \mathrm{~kg} / \mathrm{ha}$ which was statistically at par with the value recorded at Gurez (178.2 kg/ha) and kargil recorded a value of $109.7 \mathrm{~kg} / \mathrm{ha}$

\section{Exchangeable calcium (centimole)}

Soil exchangeable calcium was maximum (17.56 $\left.\mathrm{Cmolp}^{+} / 100 \mathrm{~g}\right)$ at Pattan. It was followed by Gurez (10.43 Cmolp $\left.{ }^{+} / 100 \mathrm{~g}\right)$ and least in Kargil (7.33 


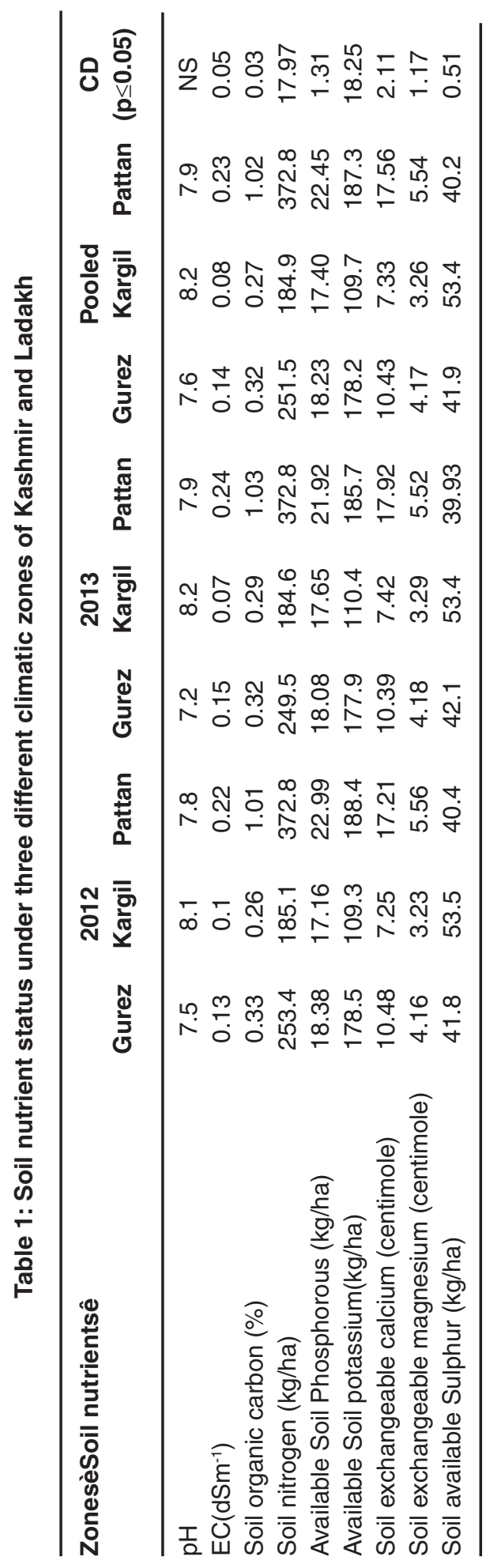

$\left.\mathrm{Cmolp}^{+} / 100 \mathrm{~g}\right)$. The values recorded during both years of study showed significant difference between three zones

\section{Exchangeable magnesium (centimole)}

Soil exchangeable magnesium was maximum at Pattan site $\left(5.54 \mathrm{Cmolp}^{+} / 100 \mathrm{~g}\right)$ whereas it was least (3.26 Cmolp ${ }^{+} / 100 \mathrm{~g}$ ) at Kargil site. Gurez on an average recorded a value of $4.17 \mathrm{Cmolp}^{+} / 100 \mathrm{~g}$. The values at Gurez and Kargil were statistically at par.

\section{Available sulphur (kg/ha)}

Available sulphur in soil was recorded maximum at Kargil during both the years of study with an average value of $53.4 \mathrm{~kg} / \mathrm{ha}$ being significantly different from other two zones which recorded average values of 41.9 and $40.2 \mathrm{~kg} / \mathrm{ha}$ for Gurez and Pattan respectively .

The findings of soil status show variations under agroclimatic conditions. Soils generally differ in their salt content. The $\mathrm{pH}$ of Kargil soils could be attributed to leaching of basis and variation in organic matter as reported by Minhas and Bora (1982). The present findings are in conformity with the findings of Wani (2001) and Dar (2009) who have analyzed the soils of orchards of Kashmir valley. The variation in electric conductivity under three different agro-climatic zones could be attributed to leaching of soluble salts from surface to subsurface horizons. Similar reports have been given by Marazi (1988), while studying soils of apple orchards. Organic carbon is the index of soil fertility and productivity (Nagaveni et al., 2003). Soil organic carbon appears to be an important parameter that controls sustainability of crop production (Lal, 2004). The organic matter in soil promotes the formation of desirable soil structure and thus influences the aeration and retention of moisture (Subbiah and Asija, 1956).

The presence of highest organic carbon in soil of Pattan area could be attributed to the mixing of crop residues and fallen leaves into soil system after the harvest as a large number of fruit orchards and other crops are cultivated in Pattan area in contrast to Gurez and Kargil where less crops are cultivated and thus depicting low organic carbon in the soils. These observations have also been 
reported by Lahiri and Chakravarti (1989). Further left over crop residues and fallen leaves have also resulted in increased interaction with soil microbial complex there by changing $\mathrm{C}: \mathrm{N}$ ratio. The same has also been reported by Samanta et al. (2001).

Present findings showed higher available nitrogen,phosphorus and potassium in the soils of Pattan site followed by Gurez and least in Kargil. The decreasing nitrogen, phosphorus and potassium in three agroclimatic zones viz; Pattan, Gurez and Kargil respectively could be attributed to higher amounts of organic matter which is an important source of phosphorus and nitrogen; soils with more amount of clay absorb more phosphorus and potassium. The results are in conformity with findings of Najar et al. (2005).

The study further showed that soil exchangeable calcium and soil exchangeable magnesium was highest in the soils of Pattan site followed by Gurez and least at Kargil. The variation in calcium and magnesium content can be attributed to parent material of soil while as the higher sulphur at Kargil than other two agroclimatic zones can be attributed to increased crop yields, thus remove large amount of sulphur and immobilization of sulphur in organic matter. Present findings are in conformity with the studies of Najar (2002).

\section{REFERENCES}

1. Anonymous. Digest of Statistics, Govt. of Jammu and Kashmir, Directorate of Economics and Statistics 2011.

2. Black, C.A. Methods of soil analysis, part I and II. American Society of Agronomy, Incharge Publisher, Madison Wisconsin, USA 1965.

3. Chesnin, L. and Yien, C.H. 1951. Turbidimetric determination of available sulfates. Proceedings of Soil Science Society of America 15 : 149-151.

4. Dar, M.A. Effect of altitude on nutritional status of pear orchard soils of Kashmir valley. Ph.D thesis submitted to Sher-e-Kashmir University of Agricultural Sciences \& Technology of Kashmir, Shalimar, pp 216; 2009.

5. Lahiri, T. and Chakravarti, S.K. Characteristics of some soils of Sikkim at various altitudes. Journal of the Indian Society of Soil Science, 1989; 37 : 451-454.

6. Lal, R. 2004. Soil quality in industrialized and developing countries - similarities and differences. In : Managing Soil Quality, Challenges in Modern Agricutlure, 2004 (Eds. P. Schjnning, S. Elmholt and B.T. Christernsen). CAB International, pp 297313.

7. Mervein, H.D. and Peech, M. Exchangeability of soil potassium in the sand, silt and clay fraction as influenced by the nature of complementary exchangeable cations. Soil Science Society of America Proceedings, 1950; 15 : 125-128.
8. Minhas, R.S. and Bora, N.C. Distribution of organic carbon and the forms of nitrogen in topographic sequence of soil. Journal of the Indian Society of Soil Science, 1982; 30: 135139.

9. Marazi, A.R. Effect of different nitrogen levels and water regimes on yield and growth of rice. M.Sc thesis submitted to Sher-eKashmir University of Agricultural Sciences \& Technology of Kashmir, Shalimar, 1988; pp 120.

10. Najar, G.R. Studies on pedogenesis and nutrient indexing of apple (Red Delicious) growing soils of Kashmir. Ph.D. thesis submitted to Sher-e-Kashmir University of Agriculture Sciences and Technology of Kashmir, Shalimar, Srinagar 2002.

11. Nagaveni, V., Shree, M.P. and Shivashankara, B.R. 2003. Comparative study of soil fertility status in mulberry gardens of Mandya, Tumkur and Kolar districts of Karnataka. In : Nutritional Management and Quality Improvement in Sericulture. Proc. Natl. Sem. Mulb. Seri. Res. India, 2001. [Eds. U.D. Bongale], KSSRDI, Bangalore, pp. 175-178.

12. Najar, G.R., Farida, A. and Rahman, F.H. Mineral nutrient status of apple orchards of Kashmir. SKUAST Journal of Research, 2005; 7: 271-275.

13. Olsen, S.R., Cole, C.V., Watanabe, F.S. and Dean, L.A. Estimation of a available phosphorus in soils by extraction with sodium 
bicarbonate. USDA Circular, 1954; 939 : 1-19.

14. Subbiah, B.V. and Asija, G.L. A Rapid procedure for estimation of available nitrogen in soils. Current Science, 1956; 25: 259261.

15. Samanta, A., Chatterjee, A.K., Kar, R. And Mandal, B. Assessment of maganese content in mulberry garden soils of West Bengal. Indian Journal of Sericulture, 2001; 40(1) : 64-70.

16. Singhvi, N.R., Subbaswamy, M.R., Kodandaramaiah, J. and Sarkar, A. Nutrient requirement-supply gap in mulberry; an analysis. Plant Archives, 2006; 6(1) : 57-64.

17. Walkley, A. and Black, I.A. An examination of the Degtjareff method for determining soil organic matter and proposed modification of chomic acid titration method. Soil Science, 1934; 37(1) : 29-38.

18. Wani, G.N. Studies on the distribution of secondary nutrient elements ( $\mathrm{Ca}, \mathrm{Mg}$ and $\mathrm{S}$ ) in apple orchard soils of north Kashmir. M.Sc. thesis submitted to Sher-e-Kashmir University of Agriculture Sciences and Technology of Kashmir, Shalimar, 2001; pp. 75. 